\title{
Multitopic Supramolecular Detection of Chemical Warfare Agents by Fluorescent Sensors
}

\author{
Roberta Puglisi, ${ }^{\dagger}$ Andrea Pappalardo, ${ }^{\dagger, \ddagger}$ Antonino Gulino, ${ }^{\dagger, \ddagger(0)}$ and Giuseppe Trusso Sfrazzetto ${ }^{*}, \dagger, \ddagger$ (1) \\ †Department of Chemical Sciences, University of Catania, Viale A. Doria 6, 95100 Catania, Italy \\ "University of Catania Research Unit (I.N.S.T.M.) UdR of Catania, Viale A. Doria 6, 95125 Catania, Italy
}

Supporting Information

\begin{abstract}
Two new naphthalimide derivatives (hosts), bearing one or two ethanolamine arms, respectively, were synthesized and tested as fluorescent probes for the detection of a chemical warfare agent simulant (guest). The resulting host-guest hydrogen bonds allowed a recognition mechanism based on supramolecular interactions. The sensor with two ethanolamine groups showed excellent sensibility and selectivity in a turn-on fluorescent response.
\end{abstract}

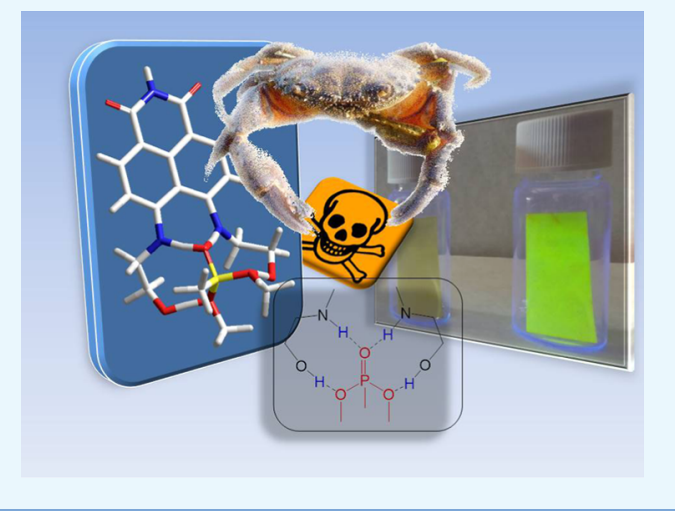

\section{INTRODUCTION}

Terrorist attacks are nowadays the most dangerous threat in the international scenario. In particular, some of these attacks have already been conducted by using chemical substances, called chemical warfare agents (CWAs). Although CWAs are outlawed and prohibited in many countries, the recent terrorist attacks in the Middle East and also in Europe highlight the importance to detect in real time the presence of these agents. ${ }^{1}$ From a chemical point of view, CWAs are organophosphorus (OP) compounds, classified into $\mathrm{G}$ and V series. ${ }^{2,3}$ For security reasons, the use of these compounds is precluded also for research activity; thus, the development of new and more efficient sensors and relative recognition studies can only be conducted by using less toxic simulants, such as dimethyl methylphosphonate (DMMP). ${ }^{4 a, b}$ In fact, recent studies demonstrated that DMMP is one of the best simulants for $G$ series nerve agents. ${ }^{4 c}$ The detection via mass spectrometry is very sensitive but, due to the instrumental complexity, difficult to be realized in real time. Thus, sensing by using molecular probes is the preferred way. Recently, two mechanisms have been exploited in the CWAs recognition: (i) the covalent and (ii) the supramolecular approaches. The covalent mechanism is based on a covalent and irreversible reaction between the sensor and the analyte, leading to a detectable response. ${ }^{5}$ The main limitations of this approach are represented by scarce selectivity, impossibility to reuse the sensor, and some falsepositive responses. ${ }^{6}$ Conversely, the more recent supramolecular approach shows many advantages. ${ }^{7}$ In fact, the possibility to exploit noncovalent interactions leads to a reversible detection mechanism thus affording reusable sensors. $^{8}$ In addition, a "multitopic approach" involves more than one site of the OP analyte, thus increasing the selectivity. ${ }^{9}$
Therefore, this new frontier of "supramolecular recognition of CWAs via a multitopic approach" paves the way for a new generation of CWAs sensors. In fact, the chemical structures of the proposed receptors are designed to simultaneously recognize two or more sites of the target analyte, thus increasing the selectivity and reducing the false-positive responses. So far, few examples of supramolecular sensors that interact with the simulant by hydrogen bonds (gel) ${ }^{10-15}$ or hydrophobic effects (synthetic macrocycles), ${ }^{16-20}$ have been reported. In both these examples, the recognition mechanisms are based on a monotopic approach. Recently, our research group has developed the first example of a multitopic receptor based on two different recognition sites. 9

In the present study, we report on the syntheses of two new fluorescent sensors that show one or two ethanolamine arms (naphthyl-mono-AE and naphthyl-di-AE, Chart 1), respectively, for the detection of DMMP via a multitopic supramolecular approach.

In particular, these new probes allow the formation of multiple hydrogen bonds with the DMMP analyte, thus increasing the affinity and selectivity. Molecular recognition studies have been performed by using fluorescence, UV-vis, one-dimensional-two-dimensional NMR (1D-2D NMR), and mass spectrometry. Naphthyl-di-AE shows many advantages with respect to already reported sensors. ${ }^{11-20}$ In fact, it represents the first multitopic/metal-free/turn-on fluorescent sensor that is able to recognize DMMP with high selectivity. In addition, the easy synthetic pathway, the large Stock-shift

Received: February 22, 2019

Accepted: April 8, 2019

Published: April 25, 2019 
Chart 1. Chemical Structures of Naphthyl-mono-AE (Left) and Naphthyl-di-AE (Right)

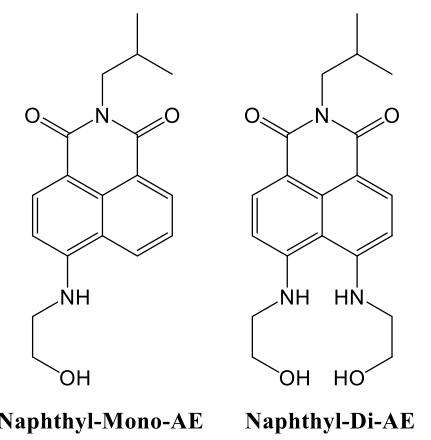

emission, and the possibility to functionalize the organic scaffold to obtain heterogeneous devices pave the way for many applications of naphthyl-di-AE in real conditions.

\section{RESULTS AND DISCUSSION}

The multitopic recognition approach requires at least two binding sites for the guest. DMMP shows three possible $\mathrm{H}$ bond acceptor sites: $\mathrm{P}=\mathrm{O}$ and two $-\mathrm{OCH}_{3}$ groups that are ca. $2.3 \AA$ away from $\mathrm{P}=\mathrm{O}$ (Figure 1a). The ethanolamine

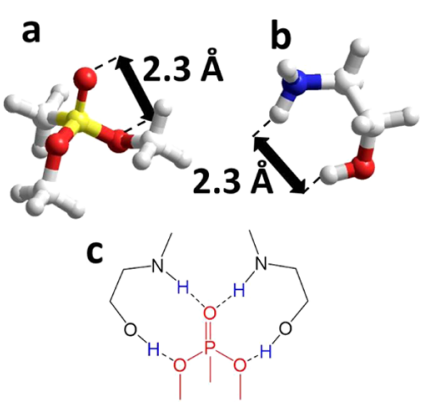

Figure 1. Geometry optimizations of (a) DMMP, (b) ethanolamine and relative distances between atoms involved in molecular recognition (force field $\mathrm{MM}+$ ), (c) multitopic proposed approach.

molecule shows appropriate geometry to simultaneously interact with $\mathrm{P}=\mathrm{O}$ and oxymethylene groups of DMMP (Figure $1 \mathrm{~b}$ ) and, Figure 1c shows the possible resulting $\mathrm{H}$ bond network. On the basis of the above considerations, we designed two molecular probes (naphthyl-mono-AE and naphthyl-di-AE), bearing naphtalimide moiety, that are able to give fluorescent response upon the recognition event. ${ }^{21,22}$

Scheme 1 reports the synthesis of the receptors. Naphthylmono-AE was synthesized starting from $\mathrm{Br}$-anhydride $\mathbf{1}$, which in the presence of isobuthylamine in ethanol led to the $\mathrm{Br}$-imide derivative $\mathbf{2}$ (see the Supporting Information). After the treatment of $\mathbf{2}$ with excess ethanolamine in 2 methoxyethanol at reflux, naphthyl-mono-AE was isolated in high yield (Scheme 1, see the Supporting Information).

Following the same synthetic strategy, naphthyl-di-AE was prepared starting from $\mathrm{Br}-\mathrm{NO}_{2}-$ anhydride 3 by using a wellknown procedure to functionalize $\mathrm{Br}-\mathrm{NO}_{2}$-naphthalimide scaffold. $^{21,22}$ A large excess of ethanolamine (10 equiv) and a longer reaction time $(36 \mathrm{~h})$ in the last step were employed.

The UV-vis spectrum of naphthyl-mono-AE shows an absorption band centered at $425.2 \mathrm{~nm}(\varepsilon=15600)$ (see the Supporting Information). The fluorescence spectrum, obtained by excitation at $\lambda_{\mathrm{ex}}=340 \mathrm{~nm}$, shows a strong emission band
Scheme 1. Synthesis of the Receptors ${ }^{a}$

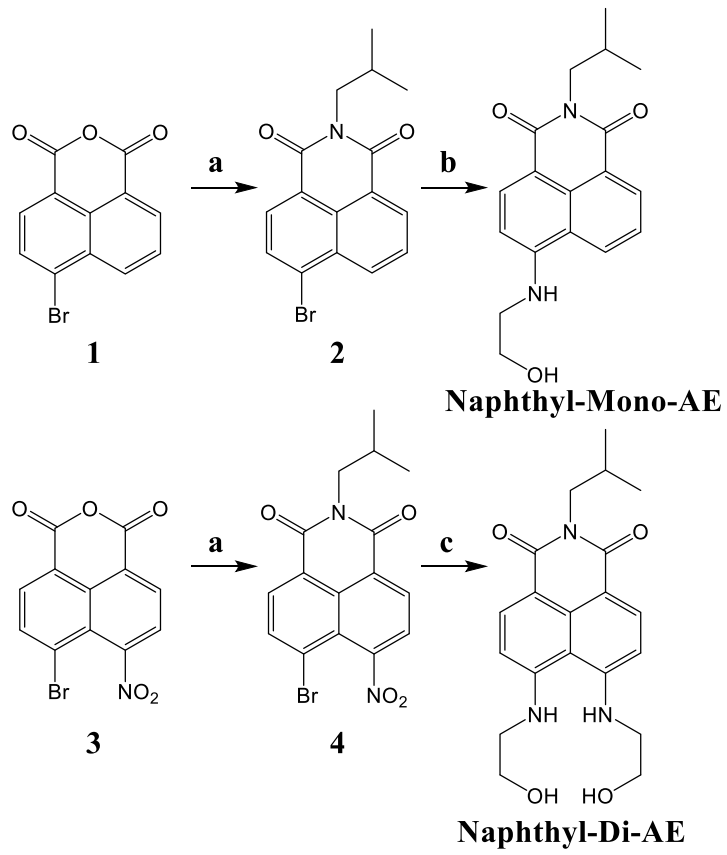

${ }^{a}$ Reagents and conditions: (a) isobuthylamine, ethanol, $50{ }^{\circ} \mathrm{C}, 18 \mathrm{~h}$, $92 \%$ for $2,56 \%$ for 4 ; (b) ethanolamine, 2-methoxyethanol, reflux, 18 h, 71\%; (c) ethanolamine, 2-methoxyethanol, reflux, 36 h, $47 \%$.

centered at $470 \mathrm{~nm}$, with a strong Stokes shift (see the Supporting Information). Recognition properties of naphthylmono-AE and DMMP were evaluated by following the increase of the emission band at $470 \mathrm{~nm}$. In particular, upon the progressive addition of the guest, a turn-on fluorescence response was observed, probably due to a photoinduced electron transfer mechanism. ${ }^{23}$ The obtained binding constant value was $3467 \mathrm{M}^{-1}$ (see the Supporting Information), in agreement with the formation of two hydrogen bonds with DMMP. $^{24}$

To increase the affinity for DMMP, we introduced a second ethanolamine arm in the naphthalimide scaffold, thus obtaining naphthyl-di-AE (see the Supporting Information). The related UV-vis spectrum shows two main bands centered at $344.6 \mathrm{~nm}$ $(\varepsilon=5100)$ and $438.4 \mathrm{~nm}(\varepsilon=19800)$, respectively (see the Supporting Information). By excitation at $340 \mathrm{~nm}$, the emission band at $509 \mathrm{~nm}$ shows a higher Stokes shift with respect to naphthyl-mono-AE, thus confirming the potential application as a real fluorescent sensor. Fluorescence measurements upon addition of progressive amounts of DMMP show a strong turn-on response (see Figure 2), with a calculated binding constant value of $10471 \mathrm{M}^{-1}$, more than 3 times larger than that observed for naphthyl-mono-AE, thus demonstrating that the introduction of the second chelating arm leads to a stronger supramolecular complex with DMMP. The increase of the binding constant value is in agreement with our previous study performed by using uranyl salen complexes. ${ }^{8,9}$ In particular, the results here obtained confirm that the presence of additional two H-bonds in the host-guest complex leads to a binding constant value 3 times higher. This result can be fundamental for the design of other CWA receptors.

The detection limit of DMMP is $1 \mathrm{ppm}$, both in the case of naphthyl-mono-AE and naphthyl-di-AE. The time-dependent fluorescence emission spectra, recorded for both receptors before and after the addition of 1 equiv of DMMP, show an 


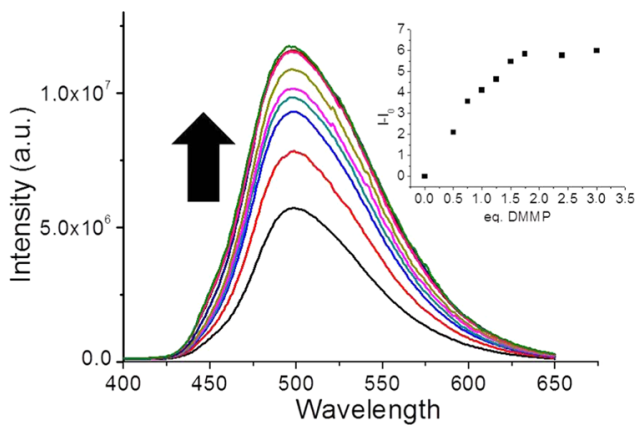

Figure 2. Fluorescence intensity behavior of naphthyl-di-AE $(1 \times$ $10^{-5} \mathrm{M}$ in dry toluene solution, $\lambda_{\text {ex }} 340 \mathrm{~nm}$ ) upon the DMMP additions; the inset shows the intensity increase upon the progressive addition of DMMP equivalents.

instant emission response, stable for at least $10 \mathrm{~min}$ (see the Supporting Information).

Electrospray ionization-mass spectrometry (ESI-MS) measurements also confirmed the supramolecular complex stoichiometry. In fact, the observed peak at $m / z=518.4$ is ascribed to the [naphthyl-di-AE@DMMP+Na] ${ }^{+}$ion (see the Supporting Information). The geometry of the host-guest system was elucidated by ${ }^{1} \mathrm{H}$ NMR experiments. In particular, titration of naphthyl-di-AE with DMMP in $\mathrm{CDCl}_{3}$ shows that (i) signals relative to $\mathrm{NH}$ and $\mathrm{OH}$ protons of the host $(6.40$ and $2.55 \mathrm{ppm}$, respectively) undergo a downfield shift after the addition of the guest in a fast-exchange mechanism compared to the ${ }^{1} \mathrm{H}$ NMR time scale (Figure 3b,d); and (ii) the multiplicity of the methylene signal of the ethanolamine moieties changes from quartet to triplet. These overall data suggest the synergy of $\mathrm{NH}$ and $\mathrm{OH}$ groups toward the DMMP chelation, thus confirming the multitopic recognition process (Figure 3a). Nonlinear curve fits relative to these data show a binding constant value of $468 \mathrm{M}^{-1}$ (Figure 3c,e), lower with respect to those obtained with fluorescence measurements, probably due to the different solvent used (toluene is less competitive than chloroform in the hydrogen bond formation).

To further confirm the geometry of naphthyl-di-AE@ DMMP supramolecular complex, TROESY measurements were also carried out (see the Supporting Information). In particular, an equimolar solution $\left(1 \times 10^{-3} \mathrm{M}\right.$ in $\left.\mathrm{CDCl}_{3}\right)$ of naphthyl-di-AE and DMMP shows ROE contacts between the methylene groups bound to the $-\mathrm{NH}$ function $(-\mathrm{NH}-$ $\mathrm{CH}_{2}-$ ) of the receptor and the $-\mathrm{OCH}_{3}$ substituent of DMMP (Figure 4). This further result unambiguously confirms the chelation of DMMP by the naphthyl-di-AE receptor.

High selectivity is of crucial importance for real applications, and the classical CWAs sensing based on covalent reactions between a nucleophilic sensor substituent and a given nerve agent simulant can lead to false-positive response due to the low specificity of this reaction. In contrast, the goal of the multitopic supramolecular approach consists in the formation of reversible interactions with more than two sites of the guest, thus increasing the selectivity and reducing the possibility of a false-positive detection.

For this reason, we also performed selectivity and competition tests. In particular, atmospheric air (in which we measured $24000 \mathrm{ppm}$ of water, $400 \mathrm{ppm} \mathrm{CO}_{2}, 5 \mathrm{ppm} \mathrm{NO}$, and $10 \mathrm{ppm} \mathrm{CO}$ ) was bubbled for $30 \mathrm{~min}$ into a $1 \times 10^{-5} \mathrm{M}$ toluene solution of naphthyl-di-AE. The fluorescence spectra of the receptor were acquired before and after air bubbling.

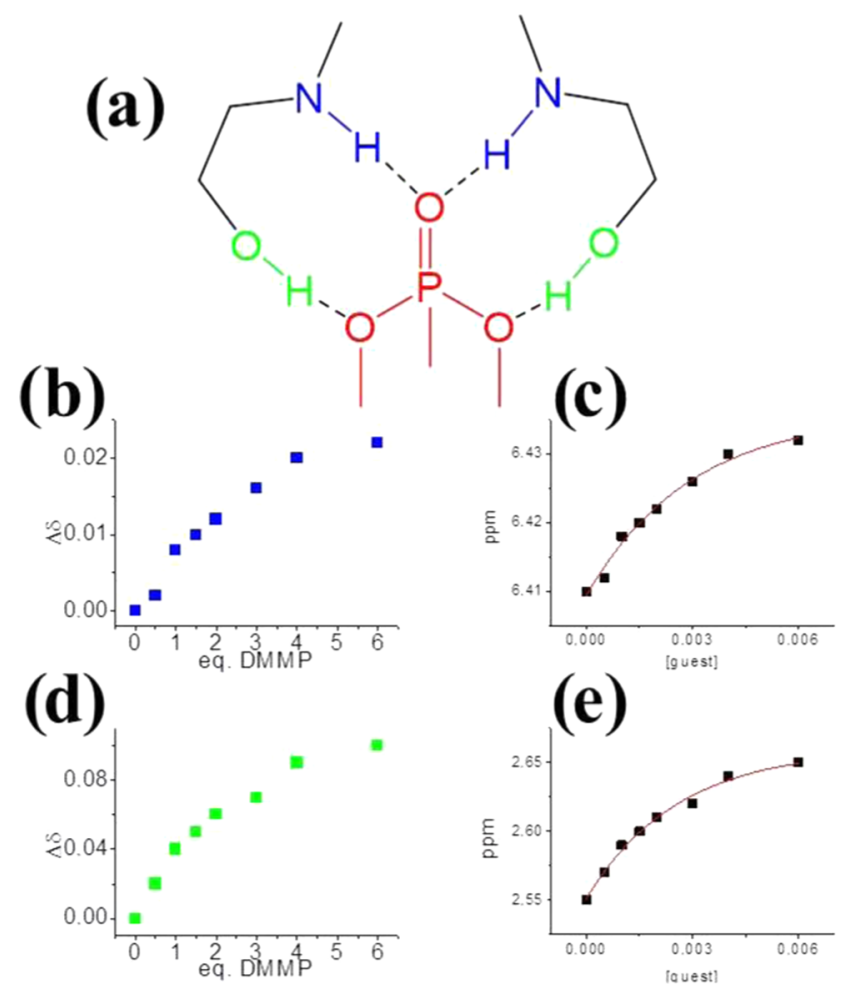

Figure 3. (a) Multitopic proposed recognition mechanism; chemical shift variation of signals relative to (b) $\mathrm{NH}$ (blue) and (d) $\mathrm{OH}$ (green) groups of the ethanolamine moieties during the ${ }^{1} \mathrm{H}$ NMR titration of naphthyl-di-AE with DMMP in $\mathrm{CDCl}_{3}$. (c, e) The nonlinear curve fits relative to $\mathrm{NH}$ and $\mathrm{OH}$, respectively; although other molecular receptors are able to detect CWAs simulant by using $\mathrm{Zn}$ as metal Lewis acid, naphthyl-di-AE recognizes DMMP without the assistance of metal ion, as confirmed by ESI-MS measurements (see the Supporting Information). In addition, we tested the ability of naphthyl-di-AE to chelate $\mathrm{Zn}^{2+}$ ion, without positive results.

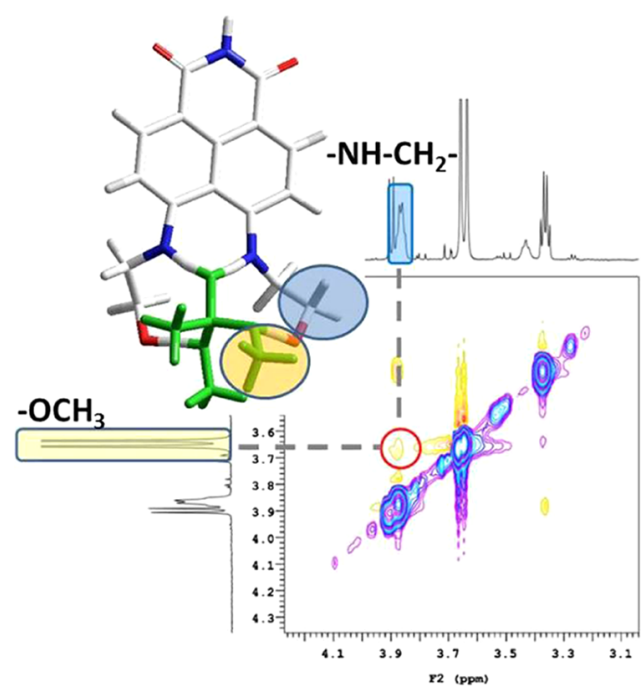

Figure 4. Selected region of the TROESY spectrum of an equimolar $\left(1 \times 10^{-3} \mathrm{M}\right.$ in $\left.\mathrm{CDCl}_{3}\right)$ solution of naphthyl-di-AE and DMMP. The inset shows the minimized structure (force field $\mathrm{MM}+$ ) of the supramolecular complex, highlighting the functional groups involved in the ROE contacts (DMMP is shown in green; isobuthyl group of the receptor was omitted for clarity).

The two obtained spectra are superimposable (see the Supporting Information), thus demonstrating that the 
fluorescence profile of naphthyl-di-AE is not affected by the standard analytes/contaminants contained in air. Then, this air-saturated naphthyl-di-AE solution was exposed to DMMP and we observed an increase in the intensity of the emission spectra. These results confirm the high selectivity of naphthyldi-AE toward DMMP also in real atmospheric conditions. Selectivity test was further conducted by using acetic acid as a competitor. Also, in this case, the naphthyl-di-AE emission remains unaffected up to 10 equiv of acetic acid.

Then, we performed a practical test using a filter paper adsorbed with naphthyl-di-AE (Test Strip, Figure 5). A

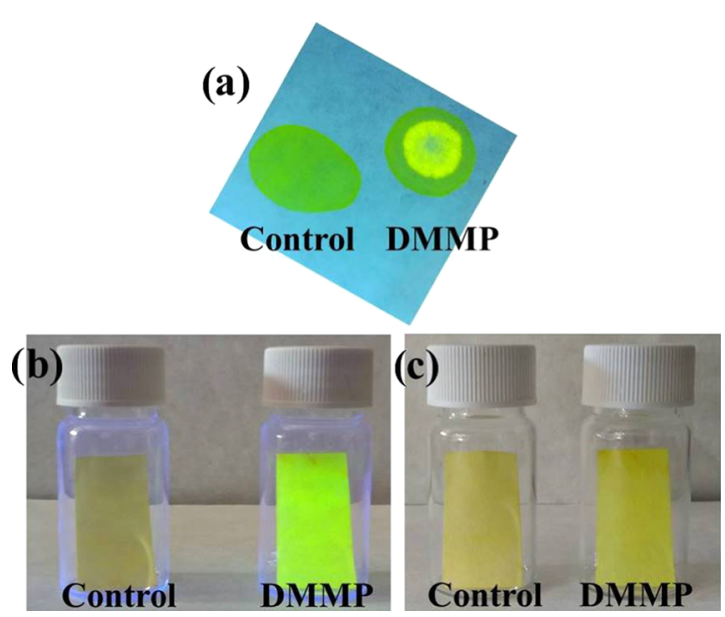

Figure 5. Test Strip with vapors and solution: (a) solution of naphthyl-di-AE $\left(1 \times 10^{-3} \mathrm{M}\right)$ adsorbed on filter paper without (control on the left) and with the presence of $1 \mu \mathrm{L}$ of DMMP (on the right) under UV-vis lamp (365 nm); (b) solution of naphthyl-di-AE $\left(1 \times 10^{-3} \mathrm{M}\right)$ adsorbed on filter paper $(2 \times 3.5 \mathrm{~cm})$ without (control on the left) and with the presence of vapors of DMMP (40 ppm, on the right) under UV-vis lamp (365 nm); (c) filter papers showed in (b) under daylight. Due to the low volatility of DMMP (bp $181^{\circ} \mathrm{C}$, vapor pressure $0.962 \mathrm{~mm} \mathrm{Hg}$ at $25^{\circ} \mathrm{C}$ ), Test Strip was conducted for $1 \mathrm{~h}$ and then the filter paper was exposed under the UV-vis lamp.

stronger fluorescent spot appeared in correspondence of the addition of a drop of simulant (Figure 5a), thus confirming the possibility of a fast and reliable practical test. Then, we adsorbed common filter paper with a $(1 \mathrm{mM})$ solution of the receptor. After its exposure to DMMP vapors (40 ppm, in a closed vial at room temperature), a clear enhancement of emission was observed, both under UV-vis (Figure 5b) and daylight (Figure 5c) irradiations.

These experiments confirm the ability of naphthyl-di-AE to detect DMMP with high affinity and sensibility, also in a common practical device.

The photostability of naphthyl-mono-AE and naphthyl-di$\mathrm{AE}$ in air was evaluated to validate these receptors for long operation time. In particular, after exposure of sensors to air and daylight for 1 month, they preserve the recognition abilities without the loss of efficiency and sensibility. This is due to the high stability of naphthalimide derivatives under normal conditions. ${ }^{25}$

\section{CONCLUSIONS}

Two new fluorescent metal-free sensors for a CWA simulant, differing in the number of ethanolamine arms, have been synthesized. Both probes recognize DMMP via multitopic supramolecular approach by the formation of a $\mathrm{H}$-bond network. The recognition event detected by fluorescence emission, with a large Stokes shift and a turn-on emission fluorescence, highlights the presence of DMMP in a solution. The probe with two ethanolamine functionalites (naphthyl-diAE) shows higher affinity for DMMP with respect to naphthyl-mono-AE. The supramolecular host-guest geometry between naphthyl-di-AE and DMMP, as well as the related stoichiometry was elucidated by ESI-MS and NMR 1D-2D measurements. Both selectivity and specificity, also in competition conditions, were evaluated thus demonstrated the importance of a multitopic approach for the recognition mechanism. Test Strip demonstrated the possibility to realize practical device for the detection of CWAs.

With the aim to realize real sensor devices, these receptors show many interesting features: (i) easy synthetic pathway; (ii) absence of metal ions; (iii) turn-on fluorescence detection of the analyte; (iv) selectivity and specificity; (v) reversibility, due to the nature of the interaction with the analyte; (vi) possibility to easily functionalize the scaffold (particularly in the imide moiety) to anchor it onto solid supports; (vii) positive to the Test Strip; and (viii) photostability and fast-emission response. Actually, we are working on the functionalization of this organic scaffold to obtain solid devices.

\section{EXPERIMENTAL SECTION}

General Experimental Methods. The NMR experiments were carried out at $27^{\circ} \mathrm{C}$ on a Varian UNITY Inova $500 \mathrm{MHz}$ spectrometer $\left({ }^{1} \mathrm{H}\right.$ at $499.88 \mathrm{MHz},{ }^{13} \mathrm{C} \mathrm{NMR}$ at $\left.125.7 \mathrm{MHz}\right)$ equipped with a pulse-field gradient module ( $Z$ axis) and a tunable $5 \mathrm{~mm}$ Varian inverse detection probe (ID-PFG). The ESI mass spectra were acquired on a ES-MS Thermo-Finnigan LCQ-DECA using $\mathrm{CH}_{3} \mathrm{CN}$ (positive or negative ion mode). Luminescence measurements were carried out using a Cary Eclipse Fluorescence spectrophotometer at room temperature. The emission was recorded at $90^{\circ}$ with respect to the exciting line beam, using 5:5 slit widths for all measurements. All chemicals were reagent grade and used without further purification. The three-dimensional minimized structure of naphthyl-di-AE was obtained by using HyperChem v8.0.7, $\mathrm{MM}+$ force field. The NMR characterization of compound $\mathbf{2}$ is in tune with the literature data. ${ }^{26}$

Procedure for ${ }^{1} \mathrm{H}$ NMR Titrations. Two mother solutions of host and guest $\left(7.0 \times 10^{-3} \mathrm{M}\right)$ in $\mathrm{CDCl}_{3}$ were prepared. From these, different solutions with different host/guest ratio were prepared, and ${ }^{1} \mathrm{H}$ NMR spectra were recorded at $27{ }^{\circ} \mathrm{C}$. TROESY spectrum was acquired by using equimolar solution of host and guest. With this data treatment, the apparent binding constants were determined using HypNMR (version 4.0.71), a software designed to extract equilibrium constants from potentiometric and/or spectrophotometric titration data.

Procedure for Test Strip. Fifty microliters of a solution of naphthyl-di-AE $\left(1 \times 10^{-3} \mathrm{M}\right.$ in $\left.\mathrm{CH}_{2} \mathrm{Cl}_{2}\right)$ was adsorbed onto two portions of filter paper $(2 \times 3.5 \mathrm{~cm})$ and solvent was removed under air flow. One of these paper filter was inserted into a vial $(20 \mathrm{~mL})$ containing $1 \mu \mathrm{L}$ of DMMP $0.1 \mathrm{M}$ in $\mathrm{CH}_{2} \mathrm{Cl}_{2}$. The other one was inserted in a vial $(20 \mathrm{~mL})$ without DMMP (control in Figure 5). Both vials were maintained at room temperature for $1 \mathrm{~h}$. After this time, filter papers were observed under UV-vis lamp at $365 \mathrm{~nm}$.

Procedure for Fluorescence Titrations. Two mother solutions of host and guest $\left(1.0 \times 10^{-3} \mathrm{M}\right)$ in dry solvent were prepared. From these, different solutions with different receptor/guest ratios were prepared, and the emission spectra 
were recorded at $25^{\circ} \mathrm{C}$. Fluorescence titrations with naphthylmono-AE and naphthyl-di-AE were carried out using $\lambda_{\text {exc }}=$ $340 \mathrm{~nm}$ in dry toluene, $\lambda_{\mathrm{em}}=470 \mathrm{~nm}$ for naphthyl-mono-AE, and $\lambda_{\text {em }}=509 \mathrm{~nm}$ for naphthyl-di-AE at $25^{\circ} \mathrm{C}$. The apparent binding affinities of receptors with DMMP were estimated using HypSpec (version 1.1.33), ${ }^{27}$ a software designed to extract equilibrium constants from potentiometric and/or spectrophotometric titration data. HypSpec starts with an assumed complex formation scheme and uses a least-squares approach to derive the spectra of the complexes and the stability constants. $\chi^{2}$ test (chi-square) was applied, where the residuals follow a normal distribution (for a distribution approximately normal, the $\chi^{2}$ test value is around 12 or less). In all of the cases, $\chi^{2} \leq 10$ were found, as obtained by 3 independent measurements sets.

Synthesis of 4-Br- $\mathrm{N}$-isobutyl-1,8-naphthalimide (2). A $1.5 \mathrm{~g}(5.4 \mathrm{mmol})$ of (1) was dissolved in $90 \mathrm{~mL}$ of absolute ethanol at $70{ }^{\circ} \mathrm{C}$ for $30 \mathrm{~min}$. Then, the mixture was kept at 50 ${ }^{\circ} \mathrm{C}$, and $800 \mu \mathrm{L}(8.1 \mathrm{mmol})$ of isobuthylamine in ethanol (20 $\mathrm{mL}$ ) was added dropwise under nitrogen. The reaction mixture was stirred at $50{ }^{\circ} \mathrm{C}$ for $18 \mathrm{~h}$, checking the reaction by thinlayer chromatography (TLC) ( $n$-hexane/ethyl acetate $7: 3$ ). The solid precipitate was filtered to give $1.7 \mathrm{~g}(5.1 \mathrm{mmol}$, yield 92\%) of (2). ${ }^{1} \mathrm{H}$ NMR (500 MHz, $\mathrm{CDCl}_{3}$ ): $\delta 8.66$ (d, $J=8.0$ $\mathrm{Hz}, 1 \mathrm{H}), 8.58$ (d, J = 7.5 Hz, $1 \mathrm{H}), 8.41(\mathrm{~d}, J=8 \mathrm{~Hz}, 1 \mathrm{H}), 8.05$ $(\mathrm{d}, J=7.5 \mathrm{~Hz}, 1 \mathrm{H}), 7.85(\mathrm{t}, J=7.5 \mathrm{~Hz}, 1 \mathrm{H}), 4.04(\mathrm{~d}, J=7.5$ $\mathrm{Hz}, 2 \mathrm{H}), 2.23(\mathrm{~m}, 1 \mathrm{H}), 0.98$ (d, $J=6.5 \mathrm{~Hz}, 6 \mathrm{H}) \mathrm{ppm}^{26}$

Synthesis of Naphthyl-mono-AE. A $0.3 \mathrm{~g}(0.9 \mathrm{mmol})$ of (2) was dissolved in 2-methoxyethanol $(30 \mathrm{~mL})$ with $600 \mu \mathrm{L}$ $(10 \mathrm{mmol})$ of ethanolamine. The reaction mixture was stirred at reflux for $18 \mathrm{~h}$ under nitrogen. Then, the solvent was removed, and the crude compound was purified by column chromatography (silica gel, $\mathrm{CHCl}_{3} / \mathrm{MeOH} 9: 1$ ) to obtain 200 $\mathrm{mg}(0.64 \mathrm{mmol}, 71 \%$ yield $)$ of naphthyl-mono-AE. ${ }^{1} \mathrm{H}$ NMR $\left(500 \mathrm{MHz}\right.$, acetone- $\left.d_{6}\right): \delta 8.60(\mathrm{~d}, J=8.5 \mathrm{~Hz}, 1 \mathrm{H}), 8.51(\mathrm{~d}, J=$ $8.5 \mathrm{~Hz}, 1 \mathrm{H}), 8.36(\mathrm{~d}, J=8.5 \mathrm{~Hz}, 1 \mathrm{H}), 7.68(\mathrm{t}, J=7.5,1 \mathrm{H})$, 6.94 (bs, $1 \mathrm{H}), 6.90(\mathrm{~d}, J=7.5 \mathrm{~Hz}, 1 \mathrm{H}), 3.97(\mathrm{~d}, J=7.5 \mathrm{~Hz}$, $2 \mathrm{H}), 3.92(\mathrm{q}, J=5.5 \mathrm{~Hz}, 2 \mathrm{H}), 3.62(\mathrm{q}, J=5.5 \mathrm{~Hz}, 2 \mathrm{H}), 2.2(\mathrm{~m}$, $1 \mathrm{H}), 0.92$ (d, $J=7.0 \mathrm{~Hz}, 6 \mathrm{H}) \mathrm{ppm} .{ }^{13} \mathrm{C}$ NMR $(125 \mathrm{MHz}$, methanol- $\left.d_{4}\right): \delta 20.7,28.8,46.9,48.2,61.1,105.4,109.5$, $121.8,123.4,126.1,129.1,131.0,132.4,136.8,152.2,166.1$, 166.5 ppm. Anal. calcd for $\mathrm{C}_{18} \mathrm{H}_{20} \mathrm{~N}_{2} \mathrm{O}_{3}$ : C, 69.21; H, 6.45; O, 15.37. Found: C, 69.18; H, 6.41; O, 15.33. ESI-MS: $m / z 336.0$ $[\mathrm{M}+\mathrm{Na}]^{+}, 353.1[\mathrm{M}+\mathrm{K}]^{+}$.

Synthesis of 4-Br-5-nitro- $\mathrm{N}$-isobutyl-1,8-naphthalimide (4). A $1 \mathrm{~g}(3.1 \mathrm{mmol})$ of $(3)^{21 \mathrm{a}}$ was dissolved in 90 $\mathrm{mL}$ of absolute ethanol at $70{ }^{\circ} \mathrm{C}$ for $30 \mathrm{~min}$. Then, the mixture was kept at $50{ }^{\circ} \mathrm{C}$, and $320 \mu \mathrm{L}(3.1 \mathrm{mmol})$ of isobuthylamine in absolute ethanol $(20 \mathrm{~mL})$ was added dropwise. The reaction mixture was stirred at $50{ }^{\circ} \mathrm{C}$ for $18 \mathrm{~h}$ under nitrogen, checking the reaction by TLC ( $n$-hexane/ethyl acetate $7: 3)$. The solid precipitate was filtered, obtaining $620 \mathrm{mg}$ (1.64 mmol, 53\% yield) of (4). ${ }^{1} \mathrm{H}$ NMR (500 MHz, $\left.\mathrm{CDCl}_{3}\right): \delta 8.71(\mathrm{~d}, J=7.5$ $\mathrm{Hz}, 1 \mathrm{H}), 8.52$ (d, $J=8.0 \mathrm{~Hz}, 1 \mathrm{H}), 8.22(\mathrm{~d}, J=8.0 \mathrm{~Hz}, 1 \mathrm{H})$, $7.93(\mathrm{~d}, J=8.0 \mathrm{~Hz}, 1 \mathrm{H}), 4.04(\mathrm{~d}, J=7.5 \mathrm{~Hz}, 2 \mathrm{H}), 2.23(\mathrm{~m}$, $1 \mathrm{H}), 0.98$ (d, $J=6.5 \mathrm{~Hz}, 6 \mathrm{H}) \mathrm{ppm} .{ }^{13} \mathrm{C}$ NMR $(125 \mathrm{MHz}$, $\left.\mathrm{CDCl}_{3}\right) \delta=163.09,162.33,135.96,132.42,131.28,130.60$, 125.74, 124.09, 123.52, 122.45, 121.22, 47.64, 27.32, 20.22 ppm. ESI-MS $m / z$ 377.1 $[\mathrm{M}+\mathrm{H}]^{+}$. Anal. calcd for $\mathrm{C}_{16} \mathrm{H}_{13} \mathrm{BrN}_{2} \mathrm{O}_{4}$ : C, 50.95; H, 3.47; O, 16.97. Found: C, $50.91 ; \mathrm{H}, 3.41 ; \mathrm{O}, 16.94$.

Synthesis of Naphthyl-di-AE. $172 \mathrm{mg}(0.46 \mathrm{mmol})$ of (4) was dissolved in $20 \mathrm{~mL}$ of 2-methoxyethanol under nitrogen atmosphere, and 10 equiv of ethanolamine was added to the solution. The reaction mixture was stirred at reflux for $36 \mathrm{~h}$. Then, the solvent was removed, and naphthyl-di-AE ( 80 $\mathrm{mg}, 0.2 \mathrm{mmol}, 47 \%$ yield) were obtained after purification by flash chromatography (silica gel, $\mathrm{CHCl}_{3} / \mathrm{MeOH}$ 9:1). ${ }^{1} \mathrm{H}$ NMR (500 MHz, $\mathrm{CDCl}_{3}$ ): $\delta 8.43(\mathrm{~d}, J=8.5 \mathrm{~Hz}, 2 \mathrm{H}), 6.74(\mathrm{~d}$, $J=8.5 \mathrm{~Hz}, 2 \mathrm{H}), 6.60(\mathrm{t}, J=5.0 \mathrm{~Hz}, 2 \mathrm{H}), 4.05(\mathrm{q}, J=5.0 \mathrm{~Hz}$, $4 \mathrm{H}), 4.01(\mathrm{~d}, J=7.5 \mathrm{~Hz}, 2 \mathrm{H}), 3.42(\mathrm{q}, J=5.0 \mathrm{~Hz}, 4 \mathrm{H}), 2.55(\mathrm{t}$ br, $2 \mathrm{H}), 2.24(\mathrm{~m}, 1 \mathrm{H}), 0.96(\mathrm{~d}, J=6.5 \mathrm{~Hz}, 6 \mathrm{H}) \mathrm{ppm} .{ }^{13} \mathrm{C}$ NMR (125 MHz, acetone- $\left.d_{6}\right): \delta 164.92,153.87,134.02$, 133.27, 112.43, 112.33, 107.74, 60.76, 47.50, 46.90, 28.09, 20.64 ppm. ESI-MS $m / z 372.3[\mathrm{M}+\mathrm{H}]^{+}, 394.2[\mathrm{M}+\mathrm{Na}]^{+}$. Anal. calcd for $\mathrm{C}_{20} \mathrm{H}_{25} \mathrm{~N}_{3} \mathrm{O}_{4}$ : C, 64.67; $\mathrm{H}, 6.78 ; \mathrm{O}, 17.23$. Found: C, 64.61; H, 6.72; O, 17.18.

\section{ASSOCIATED CONTENT}

\section{S Supporting Information}

The Supporting Information is available free of charge on the ACS Publications website at DOI: 10.1021/acsomega.9b00502.

${ }^{1} \mathrm{H}$ and ${ }^{13} \mathrm{C}$ NMR, ESI-MS, UV-vis, emission spectra, ${ }^{1} \mathrm{H}$ NMR titration, selectivity, and photostability tests (PDF)

\section{AUTHOR INFORMATION}

\section{Corresponding Author}

*E-mail: giuseppe.trusso@unict.it.

ORCID

Antonino Gulino: 0000-0002-6850-3080

Giuseppe Trusso Sfrazzetto: 0000-0003-1584-5869

Notes

The authors declare no competing financial interest.

\section{ACKNOWLEDGMENTS}

The authors thank the University of Catania (Piano della Ricerca di Ateneo 2016-2018) for financial support.

\section{REFERENCES}

(1) Stone, R. U.K. attack puts nerve agent in the spotlight. Science 2018, 359, 1314-1315.

(2) Kim, K.; Tsay, O. G.; Atwood, D. A.; Churchill, D. G. Destruction and detection of Chemical Warfare Agents. Chem. Rev. 2011, 111, 5345-5403.

(3) Stone, R. How to defeat a nerve agent. Science 2018, 359, 23.

(4) (a) Wiederoder, M. S.; Nallon, E. C.; Weiss, M.; McGraw, S. K.; Schnee, V. P.; Bright, C. J.; Polcha, M. P.; Paffenroth, R.; Uzarski, J. R. Graphene Nanoplatelet-Polymer Chemiresistive Sensor Arrays for the Detection and Discrimination of Chemical Warfare Agent Simulants. ACS Sens. 2017, 2, 1669-1678. (b) Ha, S.; Lee, M.; Seo, H. O.; Song, S. G.; Kim, K.; Park, C. H.; Kim, I. H.; Kim, Y. D.; Song, C. Structural effect of thioureas on the detection of chemical warfare agent simulants. ACS Sens. 2017, 2, 1146-1151. (c) Lavoie, J.; Srinivasan, S.; Nagarajan, R. Using cheminformatics to find simulants for chemical warfare agents. J. Hazard. Mater. 2011, 194, 85-91.

(5) (a) Zhou, X.; Lee, S.; Xu, Z.; Yoon, J. Recent progress on the development of chemosensors for gases. Chem. Rev. 2015, 115, 79448000. (b) Chen, L.; Wu, D.; Yoon, J. Recent Advances in the Development of Chromophore-Based Chemosensors for Nerve Agents and Phosgene. ACS Sens. 2018, 3, 27-43. (c) Cai, Y.-C.; Li, C.; Song, Q.-H. Fluorescent Chemosensors with Varying Degrees of Intramolecular Charge Transfer for Detection of a Nerve Agent Mimic in Solutions and in Vapor. ACS Sens. 2017, 2, 834-841. (d) Sun, X.; Dahlhauser, S.-D.; Anslyn, E.-V. New Autoinductive Cascade for the Optical Sensing of Fluoride: Application in the 
Detection of Phosphoryl Fluoride Nerve Agents. J. Am. Chem. Soc. 2017, 139, 4635-4638. (e) Liu, Y.; Bonizzoni, M. A Supramolecular Sensing Array for Qualitative and Quantitative Analysis of Organophosphates in Water. J. Am. Chem. Soc. 2014, 136, 14223-14229.

(6) Jang, Y. J.; Kim, K.; Tsay, O. G.; Atwood, D. A.; Churchill, D. G. Update 1 of: Destruction and detection of Chemical Warfare Agents. Chem. Rev. 2015, 115, PR1-PR76.

(7) (a) Ishihara, S.; Azzarelli, J. M.; Krikorian, M.; Swager, T. M. Ultratrace Detection of Toxic Chemicals: Triggered Disassembly of Supramolecular Nanotube Wrappers. J. Am. Chem. Soc. 2016, 138, 8221-8227. (b) Sambrook, M. R.; Notman, S. Supramolecular chemistry and chemical warfare agents: from fundamentals of recognition to catalysis and sensing. Chem. Soc. Rev. 2013, 42, 9251-9267.

(8) Gulino, A.; Trusso Sfrazzetto, G.; Millesi, S.; Pappalardo, A.; Tomaselli, G. A.; Ballistreri, F. P.; Toscano, R. M.; Fragalà, L. Nerve Gas Simulant Sensing by a Uranyl-Salen Monolayer Covalently Anchored on Quartz Substrates. Chem. - Eur. J. 2017, 23, 1576-1583.

(9) Puglisi, R.; Pappalardo, A.; Gulino, A.; Trusso Sfrazzetto, G. Supramolecular recognition of a CWA simulant by metal-salen complexes: the first multi-topic approach. Chem. Commun. 2018, 54, 11156-11159.

(10) Hiscock, J. R.; Piana, F.; Sambrook, M. R.; Wells, N. J.; Clark, A. J.; Vincent, J. C.; Busschaert, N.; Brown, R. C. D.; Gale, P. A. Detection of nerve agent via perturbation of supramolecular gel formation. Chem. Commun. 2013, 49, 9119-9121.

(11) Barba-Bon, A.; Costero, A. M.; Parra, M.; Gil, S.; MartínezMáñez, R.; Sancenón, F.; Gale, P. A.; Hiscock, J. R. Neutral 1,3Diindolylureas for Nerve Agent Remediation. Chem. - Eur. J. 2013, 19, $1586-1590$

(12) Sambrook, M. R.; Hiscock, J. R.; Cook, A.; Green, A. C.; Holden, I.; Vincent, J. C.; Gale, P. A. Hydrogen bond-mediated recognition of the chemical warfare agent soman (GD). Chem. Commun. 2012, 48, 5605-5607.

(13) Hiscock, J. R.; Kirby, I. L.; Herniman, J.; Langley, G. J.; Clark, A. J.; Gale, P. A. Supramolecular gels for the remediation of reactive organophosphorus compounds. RSC Adv. 2014, 4, 45517-45521.

(14) Piana, F.; Facciotti, M.; Pileio, G.; Hiscock, J. R.; Van Rossom, W.; Brown, R. C. D.; Gale, P. A. Organophosphorus chemical warfare agent simulant DMMP promotes structural reinforcement of ureabased chiral supramolecular gels. RSC Adv. 2015, 5, 12287-12292.

(15) Esipenko, N. A.; Koutnik, P.; Minami, T.; Mosca, L.; Lynch, V. M.; Zyryanov, G. V.; Anzenbacher, P., Jr. First supramolecular sensors for phosphonate anions. Chem. Sci. 2013, 4, 3617-3623.

(16) (a) Chen, S.; Ruan, Y.; Brown, J. D.; Gallucci, J.; Maslak, V.; Hadad, C. M.; Badjic, J. D. Assembly of Amphiphilic Baskets into Stimuli-Responsive Vesicles. Developing a Strategy for the Detection of Organophosphorus Chemical Nerve Agents. J. Am. Chem. Soc. 2013, 135, 14964-14967. (b) Chen, S.; Yamasaki, M.; Polen, S.; Gallucci, J.; Hadad, C. M.; Badjić, J. D. Dual-Cavity Basket Promotes Encapsulation in Water in an Allosteric Fashion. J. Am. Chem. Soc. 2015, 137, 12276-12281.

(17) Ruan, Y.; Dalkilic, E.; Peterson, P. W.; Pandit, A.; Dastan, A.; Brown, J. D.; Polen, S. M.; Hadad, C. M.; Badjic, J. D. Trapping of Organophosphorus Chemical Nerve Agents in Water with Amino Acid Functionalized Baskets. Chem. - Eur. J. 2014, 20, 4251-4256.

(18) Chen, S.; Ruan, Y.; Brown, J. D.; Hadad, C. M.; Badjic, J. D. Recognition Characteristics of an Adaptive Vesicular Assembly of Amphiphilic Baskets for Selective Detection and Mitigation of Toxic Nerve Agents. J. Am. Chem. Soc. 2014, 136, 17337-17342.

(19) Ruan, Y.; Chen, S.; Brown, J. D.; Hadad, C. M.; Badjic, J. D. Ubiquitous Assembly of Amphiphilic Baskets into Unilamellar Vesicles and Their Recognition Characteristics. Org. Lett. 2015, 17, $852-855$.

(20) Tudisco, C.; Betti, P.; Motta, A.; Pinalli, R.; Bombaci, L.; Dalcanale, E.; Condorelli, G. G. Cavitand-Functionalized Porous Silicon as an Active Surface for Organophosphorus Vapor Detection. Langmuir 2012, 28, 1782-1789.
(21) (a) Satriano, C.; Trusso Sfrazzetto, G.; Amato, M. E.; Ballistreri, F. P.; Copani, A.; Giuffrida, M. L.; Grasso, G.; Pappalardo, A.; Rizzarelli, E.; Tomaselli, G. A.; Toscano, R. M. A Ratiometric Naphthalimide Sensor for Live Cell Imaging of Copper(I). Chem. Commun. 2013, 49, 5565-5567. (b) Huang, C.; Jia, T.; Tang, M.; Yin, Q.; Zhu, W.; Zhang, C.; Yang, Y.; Jia, N.; Xu, Y.; Qian, X. Selective and Ratiometric Fluorescent Trapping and Quantification of Protein Vicinal Dithiols and in Situ Dynamic Tracing in Living Cells. J. Am. Chem. Soc. 2014, 136, 14237-14244. (c) Jang, J. H.; Bhuniya, S.; Kang, J.; Yeom, A.; Hong, K. S.; Kim, J. S. $\mathrm{Cu}^{2+}$-Responsive Bimodal (Optical/MRI) Contrast Agent for Cellular Imaging. Org. Lett. 2013, 15, 4702-4705. (d) Xu, Z.; Xiao, Y.; Qian, X.; Cui, J.; Cui, D. Ratiometric and Selective Fluorescent Sensor for CuII Based on Internal Charge Transfer (ICT). Org. Lett. 2005, 7, 889-892.

(22) Giuffrida, M. L.; Trusso Sfrazzetto, G.; Satriano, C.; Zimbone, S.; Tomaselli, G. A.; Copani, A.; Rizzarelli, E. A New Ratiometric Lysosomal Copper(II) Fluorescent Probe To Map a Dynamic Metallome in Live Cells. Inorg. Chem. 2018, 57, 2365-2368.

(23) Trusso Sfrazzetto, G.; Satriano, C.; Tomaselli, G. A.; Rizzarelli, E. Synthetic fluorescent probes to map metallostasis and intracellularfate of zinc and copper. Coord. Chem. Rev. 2016, 311, 125167.

(24) Whitaker, C. M.; Derouin, E. E.; O'connor, M. B.; Whitaker, C. K.; Whitaker, J. A.; Snyder, J. J.; Kaufmann, N. R.; Gilliard, A. R.; Reitmayer, A. K. Smart hydrogel sensor for detection of organophosphorus chemical warfare nerve agents. J. Macromol. Sci., Part A: Pure Appl. Chem. 2017, 54, 40-46.

(25) Duke, R. M.; Veale, E. B.; Pfeffer, F. M.; Kruger, P. E.; Gunnlaugsson, T. Colorimetric and fluorescent anion sensors: an overview of recent developments in the use of 1,8-naphthalimidebased chemosensors. Chem. Soc. Rev. 2010, 39, 3936-3953.

(26) Bardajee, G. R.; Li, A. Y.; Haley, J. C.; Winnik, M. A. The synthesis and spectroscopic properties of novel, functional fluorescent naphthalimide dyes. Dyes Pigm. 2008, 79, 24-32.

(27) (a) Jennings, A. R.; Son, D. Y. Efficient synthesis and anion recognition of a colorimetric preorganized tripodal thiourea compound. Tetrahedron Lett. 2012, 53, 2181-2184. (b) Pappalardo, A.; Ballistreri, F. P.; Li Destri, G.; Mineo, P. G.; Tomaselli, G. A.; Toscano, R. M.; Trusso Sfrazzetto, G. Supramolecular Polymer Networks Based on Calix[5] arene Tethered Poly(p-phenyleneethynylene). Macromolecules 2012, 45, 7549-7556. (c) Puglisi, R.; Ballistreri, F. P.; Gangemi, C. M. A.; Toscano, R. M.; Tomaselli, G. A.; Pappalardo, A.; Trusso Sfrazzetto, G. Chiral $\mathrm{Zn}-$ salen complexes: a new class of fluorescent receptors for enantiodiscrimination of chiral amines. New J. Chem. 2017, 41, 911-915. 